\title{
Synthesis of Faujasite from Fly Ash and its Applications for Hydrocracking of Petroleum Distillates
}

\author{
Sutarno* and Yateman Arryanto \\ Chemistry Department Faculty of Mathematics and natural Sciences \\ Gadjah Mada University Yogyakarta-55281
}

Presented at Symposium and Congress of MKICS 2007, 18-19 April 2007, Semarang, Indonesia

\begin{abstract}
The synthesis of faujasite from fly ash and its application for hydrocracking catalyst of heavy petroleum distillates have been performed. Faujasite was synthesized from fly ash by hydrothermal reaction in alkaline solution via combination of reflux pretreatment of fly ash with $\mathrm{HCl}$ and fusion with $\mathrm{NaOH}$. The preparation of nickel containing catalysts by ion exchange method under similar initial concentration of nickel resulted higher amount of nickel loaded on faujasite than those on zeolite Y, however, the structural damage of faujasite was higher than those of zeolite Y. In the hydrocracking of heavy petroleum distillates over Ni-faujasite and Ni-zeolite Y catalysts, the conversion of heavy gas oil fraction was the most pronounced. The selectivity toward hydrocarbons in the range of gasoline and kerosene obtained over Ni-faujasite catalyst was lower compared to those of Ni-zeolite Y reference catalyst. (C) 2007 CREC UNDIP. All rights reserved.
\end{abstract}

Keywords: fly ash; hydrothermal; faujasite; hydrocracking

\section{Introduction}

Recently, many researchers showed that various types of zeolites could be produced from fly ash by hydrothermal reaction in alkaline solution. Although zeolites have been synthesized from fly ash, most previous studies, however, showed that the final products were generally a mixture of zeolite materials, such as zeolite $\mathrm{P}$, zeolite A, faujasite, analcime, and hydroxysodalite (Lin and Hsi, 1995; Singer and Berkgaut, 1995; Amrhein et al., 1996; Shih and Chang, 1996; Querol et al., 1997). Since the zeolite materials obtained from fly ash usually contain undesired impurity phases, therefore, ef- forts to achieve the single-phase (selective) zeolites are very important. Attempts to convert fly ash into selective zeolite have been done using many pretreatments before hydrothermal reaction such as fusion with $\mathrm{NaOH}$ (Shigemoto et al., 1993; Chang and Shih, 2000; Sutarno et al., 2000) as well as ageing and seeding (Zhao et al., 1997; Sutarno et al., 2001).

By fusion with sodium hydroxide, most of the fly ash particles were converted into sodium salts such as silicate and aluminate, from which hydrothermal reaction without stirring favorably re-

* Corresponding Author.

E-mail address: sutarno@ugm.ac.id; sutarno_ugm@yahoo.com (Sutarno) 
sulted in the formation of faujasite with crystallinity as high as $62 \%$ of commercial zeolite X (Shigemoto et al., 1993). Although this method can selectively produce faujasite type zeolite (zeolite X), however, it was clear that the crystallinity of the product was not high enough. Based on the Shigemoto's method, Chang and Shih (2000) have developed a general method for conversion of different fly ashes with a wide range of chemical compositions into zeolites as ion exchangers by separating the supernatant from the sediment of fused fly ash solution. It was found that the supernatant of the dissolved fused fly ash solution could produce purer faujasite. The improved result that containing $83.1 \%$ of commercial zeolite $\mathrm{X}$ was probably related to the fact that unreacted fly ash has been separated from the supernatant. Previously, zeolite were precipitated within the fly ash solutions and mixed with the fly ash therefore it was difficult to separate the precipitated zeolites from the unreacted fly ash. The formation of zeolites from the supernatant of the fused fly ash solution demonstrated that zeolites could be separated from unreacted fly ash.

Although selective faujasite has been synthesized by fusion as well as seeding and ageing pretreatments, however, the results still showed relatively low crystallinity for fusion method and showed an impurity phase like mullite for seeding and ageing method. Therefore, attempts to convert fly ash into faujasite both without any impurities of other zeolite phases and initial phases as well as having higher crystallinity are still clearly challenging. In addition, the resulted faujasite are expected to be used for catalytic application. For catalytic application, the zeolite with higher $\mathrm{Si} / \mathrm{Al}$ mol ratio showed a higher thermal stability, therefore the resulted faujasite should have a higher $\mathrm{Si} / \mathrm{Al} \mathrm{mol}$ ratio (silicon rich-faujasite or zeolite $\mathrm{Y}, \mathrm{Si} / \mathrm{Al} \mathrm{mol} \mathrm{ratio=1.5-3.5).}$

In this investigation, synthesis of faujasitetype zeolite from fly ash was conducted by hydrothermal reaction in alkaline solution via combination of reflux with $\mathrm{HCl}$ and fusion with $\mathrm{NaOH}$. Reflux pretreatment with $\mathrm{HCl}$ was performed not only to increase the $\mathrm{Si} / \mathrm{Al}$ mol ratio but also to decrease the metal impurities in the fly ash sample (Susilowati et al., 2000).

\section{Materials and Methods}

\section{Synthesis of faujasite from fly ash}

The fly ash sample was taken from Suralaya Power Plant, Serang-Banten, Indonesia. Other chemicals used in this investigation were $\mathrm{NaOH}$ pellets (Merck), $\mathrm{HCl}$ 37\% (Merck), and distilled water (laboratory made).
A mixture of $10 \mathrm{~g}$ of fly ash sample and 100 $\mathrm{mL}$ of $\mathrm{HCl}$ was refluxed at $90^{\circ} \mathrm{C}$ for 1 hour with magnetically stirring. The solid was repeatedly washed with water and dried at $100^{\circ} \mathrm{C}$ overnight. The refluxed-fly ash was added with $\mathrm{NaOH}$ pellets, milled, and subsequently heated in a nickel crucible at $550^{\circ} \mathrm{C}$ for 1 hour. The resultant fusedrefluxed-fly ash was cooled to room temperature, milled again, and then stirred magnetically in a Teflon beaker with $100 \mathrm{~mL}$ water overnight. The slurry was heated in stainless steel autoclave with Teflon beaker inside under autogenous pressure at $100^{\circ} \mathrm{C}$ for 72 hours without any stirring. After cooling to room temperature, the resulting solid product was recovered by filtration on a Buchner funnel, washed repeatedly with water and dried in an oven at $100^{\circ} \mathrm{C}$ overnight.

The chemical composition of the fly ash, the fly ash after reflux pretreatment (refluxed-fly ash), and the zeolites obtained were determined by chemical analysis. Silicon and aluminum were measured by UV-Vis spectrometer (Hitachi 150-20 UV-Visible) whereas $\mathrm{Fe}, \mathrm{Ca}, \mathrm{K}$ and $\mathrm{Na}$ were measured by atomic absorption spectrometer (Nippon Jarrel Ash AA782). X-ray diffraction (XRD) patterns were obtain by powder method using Ni-filtered CuKa radiation at $40 \mathrm{kV}$ and $30 \mathrm{~mA}$ with scanning speed of $4 \%$ minute (Shimadzu XRD-6000). Samples were normally scanned in the $2 \theta$ range of 5 to $40^{\circ}$. Nitrogen adsorption measurements were performed on a NOVA 1200 microanalyzer (QUANTACHROME) at liquid nitrogen temperature. The sample was normally outgassed at $200^{\circ} \mathrm{C}$ for at least 4 hours under vacuum $\left(10^{-4}\right.$ torr $)$. The sample was then subjected to automatic analysis.

\section{Catalytic applications for hydrocracking of petroleum distillates}

The Ni-containing faujasite from fly ash and zeolite $\mathrm{NaY}$ (as reference) were prepared by ion exchange using $\mathrm{Ni}\left(\mathrm{NO}_{3}\right)_{2}$ solutions. A mixture of 5 $\mathrm{g}$ of zeolites sample (faujasite from fly ash or zeolite $\mathrm{NaY}$ ) and $100 \mathrm{~mL}$ of $\mathrm{Ni}$ solution was heated at $55^{\circ} \mathrm{C}$ and rotated for 24 hours. The resulting solid product was recovered by filtration on a Buchner funnel, washed repeatedly with water and dried in an oven at $100^{\circ} \mathrm{C}$ overnight. The amount of $\mathrm{Ni}$ loaded on the zeolite structure was measured by atomic absorption spectrometer (Perkin Elmer 3110). The Ni-containing zeolite was then calcined at $450^{\circ} \mathrm{C}$ for 5 hours with $\mathrm{N}_{2}$ flow of $150 \mathrm{~mL} /$ minute followed by oxidation at $450^{\circ} \mathrm{C}$ for 5 hours with $\mathrm{O}_{2}$ flow of $150 \mathrm{~mL} / \mathrm{minute}$ and reduction at $450^{\circ} \mathrm{C}$ for 5 hours with $\mathrm{H}_{2}$ flow of $150 \mathrm{~mL} / \mathrm{minute}$. The influence of the amount of Ni loaded on the crystallinity of the zeolite structure was measured by X-ray diffractometer (Shimadzu XD-3H, Shimadzu XRD- 
6000).

Catalytic studies were carried out for hydrocracking of heavy petroleum distillates. Approximately 2 $\mathrm{g}$ catalyst and $4 \mathrm{~g}$ heavy petroleum distillates of $200-300^{\circ} \mathrm{C}$ which were distilled from Minas crude oil were charged for each experiment. Hydrocracking was conducted at $320^{\circ} \mathrm{C}$ for 45 minutes with $\mathrm{H}_{2}$ flow of $150 \mathrm{~mL} /$ minute. Heavy petroleum distillates as feed and liquid products were then analyzed by gas chromatography (Shimadzu GCMS QP-5000, Shimadzu GC-17A). In comparison, the similar hydrocracking was also conducted over thermal and fly ash hydrocracking.

\section{Results and Discussion}

\section{Synthesis of faujasite from fly ash}

The faujasite obtained was designed for catalytic application; therefore, the faujasite obtained not only have to show a higher thermal stability but also the presence of metal impurities in the faujasite should be controlled. According to Susilowati et al. (2000), reflux with $\mathrm{HCl}$ was an effective pretreatment to increase $\mathrm{Si} / \mathrm{Al} \mathrm{mol}$ ratio and to decrease metal impurities in the fly ash. In this investigation, pretreatment was conducted by reflux with $\mathrm{HCl}$ followed by fusion with $\mathrm{NaOH}$. Figure 1 showed the XRD pattern of the zeolite obtained for hydrothermal time of 72 hours via combination of reflux with various $\mathrm{HCl}$ concentrations and fusion with various $\mathrm{NaOH} / \mathrm{fly}$ ash weight ratio.

Synthesis of faujasite from fly ash via combination of reflux with $\mathrm{HCl}$ and fusion with $\mathrm{NaOH}$

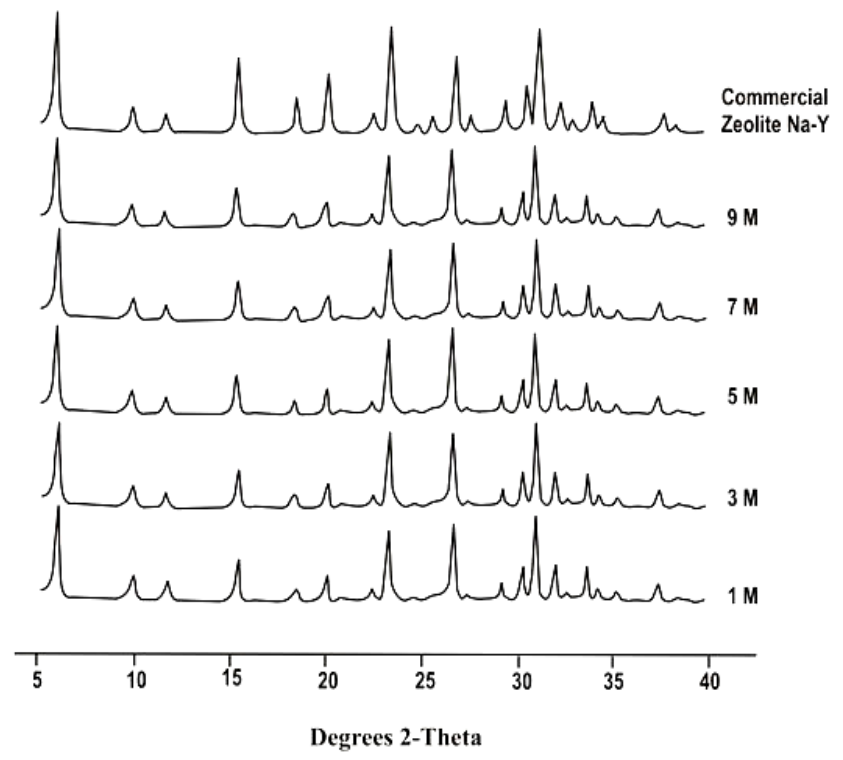

Figure 1. XRD pattern of the zeolite obtained for hydrothermal time of 72 hours via combination of reflux with various $\mathrm{HCl}$ concentrations and fusion with $\mathrm{NaOH} /$ fly ash weight ratio of 1.2 pretreatment has resulted faujasite selectively (Figure 1 and 2). The Si/Al mol ratios of the faujasite obtained by reflux pretreatment with various $\mathrm{HCl}$ concentrations were quite similar (2.56-2.68). Faujasite obtained by reflux pretreatment with various $\mathrm{HCl}$ concentrations also showed a quite similar specific surface area (412.69-452.93 m2/g). Both the $\mathrm{Si} / \mathrm{Al}$ mol ratios and the specific surface areas of the faujasite obtained with reflux pretreatment were generally lower compared to commercial zeolite NaY but were higher compared to faujasite without reflux pretreatment as presented in Table 1.

The higher Si/Al mol ratios of faujasite obtained with reflux pretreatment compared to faujasite without reflux pretreatment may be due to the higher $\mathrm{Si} / \mathrm{Al}$ mol ratio of refluxed fly ash. The relatively low specific surface area of faujasite from fly ash compared to commercial zeolite $\mathrm{NaY}$ may be due to the presence of unreacted fly ash together with faujasite (Shigemoto et al., 1993). It was shown that reflux with $5 \mathrm{M} \mathrm{HCl}$ followed by fusion

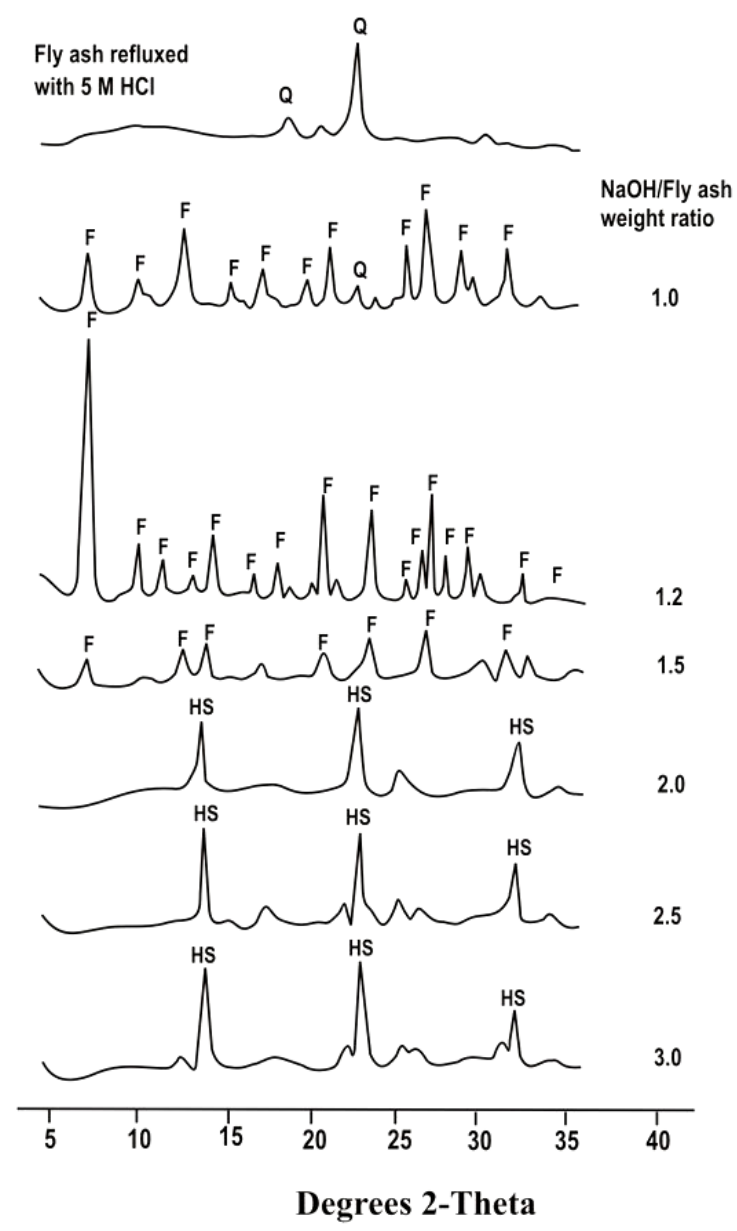

Figure 2. X-ray diffraction pattern of the zeolite obtained by reflux pretreatment with $5 \mathrm{M}$ $\mathrm{HCl}$ concentration and fusion with various $\mathrm{NaOH} /$ fly ash weight ratios $(\mathrm{F}=$ faujasite, HS=hydroxysodalite and $\mathrm{Q}=$ quartz) 
Table 1. The influence of reflux pretreatment with various $\mathrm{HCl}$ concentrations on the crystallinity, Si/Al mol ratio, and specific surface area of the faujasite obtained for hydrothermal time of 72 hours (fusion pretreatment with $\mathrm{NaOH} /$ fly ash weight ratio of 1.2 )

\begin{tabular}{|c|c|c|c|}
\hline HCl Concentration (M) & $\begin{array}{c}\text { Crystallinity of fau- } \\
\text { jasite (\%) }^{\boldsymbol{a}}\end{array}$ & Si/Al mol ratio & Specific surface area $\left(\mathbf{m}^{2} / \mathbf{g}\right)$ \\
\hline 1 & 64.28 & 2.66 & 452.88 \\
\hline 3 & 70.05 & 2.61 & 427.23 \\
\hline 5 & 97.06 & 2.68 & 452.93 \\
\hline 7 & 68.45 & 2.56 & 428.99 \\
\hline 9 & 62.94 & 2.59 & 412.69 \\
\hline Commercial zeolite NaY $^{\text {Without reflux }}{ }^{b}$ & 100.00 & 3.31 & 569.76 \\
\hline
\end{tabular}

Table 2. The influence of fusion with various $\mathrm{NaOH} / \mathrm{fly}$ ash weight ratios on the crystallinity, $\mathrm{Si} / \mathrm{Al} \mathrm{mol}$ ratio, and specific surface area of the faujasite (reflux pretreatment was done using $5 \mathrm{M} \mathrm{HCl}$ )

\begin{tabular}{|c|c|c|c|}
\hline NaOH/fly ash weight ratio & $\begin{array}{c}\text { Crystallinity of fau- } \\
\text { jasite (\%) }\end{array}$ & $\begin{array}{c}\text { Si/Al mol } \\
\text { ratio }\end{array}$ & Specific surface area (m²/g) \\
\hline 1.0 & 73.00 & 1.99 & 407.30 \\
\hline 1.2 & 97.06 & 2.68 & 452.93 \\
\hline 1.5 & 30.67 & 1.71 & 362.45 \\
\hline Commercial zeolite NaY & 100.00 & 3.31 & 569.76 \\
\hline Refluxed-fly ash $b$ & - & 2.79 & 66.32 \\
\hline
\end{tabular}

pretreatment with $\mathrm{NaOH} / \mathrm{fly}$ ash weight ratio of 1.2 (Table 1 and 2) showed the optimum condition for the synthesis of faujasite from fly ash.

The faujasite obtained via combination of reflux and fusion pretreatment showed high thermal stability up to $700^{\circ} \mathrm{C}(92.90 \%$ crystallinity $)$. In contrast, commercial zeolite $\mathrm{NaY}$ still showed a higher structural stability (76.55\% crystallinity) at $800 \mathrm{oC}$. Complete structural damage of faujasite from fly ash and commercial zeolite $\mathrm{NaY}$ into amorphous phase occurred at about 800 and $900^{\circ} \mathrm{C}$, respectively (Table 3 ). The relatively higher stability of commercial zeolite $\mathrm{NaY}$ compared to faujasite clearly proved that commercial zeolite $\mathrm{NaY}$ had higher $\mathrm{Si} / \mathrm{Al}$ mol ratio (3.31) than faujasite from fly ash (2.68) as shown in Table 1 .

\section{Catalytic application for hydrocracking of petroleum distillates}

Nickel loading on the zeolite structures was conducted by ion exchange process. Table 4 showed the amount of nickel loaded and the crystallinity of Ni-faujasite and Ni-zeolite Y catalysts as a function of initial nickel concentration on faujasite compared to those on zeolite $\mathrm{Y}$ for various $\mathrm{Ni}^{2+}$ concentrations. Due to the lower $\mathrm{Si} / \mathrm{Al}$ ratio of faujasite (see Table 1 and 2), the amount of nickel loaded on faujasite was higher than those on zeolite Y. In general, it revealed that the amount of nickel loaded on the zeolite structure sharply increased by increasing nickel concentration. A further increase of nickel concentration gradually increased the nickel loaded and the nickel loaded became relatively constant at higher nickel concentration. Under similar initial concentration of nickel, the structural damage of faujasite was higher than those of zeolite $\mathrm{NaY}$. Increasing the amount of nickel loaded experienced more structural damage. The transition metal ion solutions are generally acidic because of hydrolysis. Due to the presence of aluminate sites in the zeolite framework, however, these aluminate sites lead to zeolites unstable at low $\mathrm{pH}$, because aluminate sites are more basic than silicate sites that are preferred to be attacked by $\mathrm{H}^{+}$. As a result, removal of $\mathrm{Al}$ from the frame- 
Table 3. Crystallinity of faujasite from fly ash and commercial zeolite NaY against heat treatment at various temperatures

\begin{tabular}{|c|c|c|}
\hline \multirow{2}{*}{$\begin{array}{c}\text { Temperature } \\
\left({ }^{\circ} \mathbf{C}\right)\end{array}$} & \multicolumn{2}{|c|}{ Crystallinity (\%) $^{a}$} \\
\cline { 2 - 3 } & Faujasite from fly ash & Commercial zeolite NaY $^{2}$ \\
\hline 100 & 97.06 & 60.00 \\
\hline 400 & 74.75 & 65.51 \\
\hline 500 & 88.65 & 70.22 \\
\hline 600 & 94.91 & 66.67 \\
\hline 700 & 92.90 & 72.00 \\
\hline 800 & 3.37 & 76.55 \\
\hline 900 & 0 & 0 \\
\hline
\end{tabular}

Table 4. The crystallinity of Ni-faujasite, Ni-zeolite Y catalysts as a function of initial Ni concentration

\begin{tabular}{|c|c|c|c|c|}
\hline \multirow{2}{*}{$\begin{array}{c}\text { Initial Ni conc. } \\
(\mathbf{M})\end{array}$} & \multicolumn{2}{|c|}{ Ni-faujasite } & \multicolumn{2}{c|}{ Ni-zeolite Y } \\
\cline { 2 - 5 } & Ni loaded (\%) & Crystallinity (\%) & $\begin{array}{c}\text { Ni loaded } \\
\text { (\%) }\end{array}$ & Crystallinity (\%) \\
\hline 0.000 & 0.00 & 100.00 & 0.00 & 100.00 \\
\hline 0.050 & 2.38 & 76.04 & 2.22 & 97.20 \\
\hline 0100 & 3.18 & 62.78 & 2.51 & 95.40 \\
\hline 0.150 & 3.51 & 74.50 & 2.68 & 81.95 \\
\hline 0.200 & 3.65 & 71.60 & 2.92 & 77.64 \\
\hline
\end{tabular}

work will readily occur leading to partially loosen or even break down the crystalline zeolite structure. Increasing nickel concentration can increase the amount of $\mathrm{H}^{+}$released in the solution resulting an increase of structural damage of the zeolites. In this investigation, the $\mathrm{Si} / \mathrm{Al}$ mol ratio of faujasite was lower than those of zeolite $\mathrm{NaY}$. Therefore, the higher amount of framework-Al in faujasite leads to a higher structural damage compared to zeolite $\mathrm{NaY}$.

The structural damage of zeolites may also be generated by direct interaction between the nickel cations and the framework oxygen atoms. The direct interaction leads to the framework contraction or even structural damage due to stronger Coulomb attraction of the nickel cations with the framework oxygen atoms than those of sodium cations and the framework oxygen atoms. The interaction increased as both the nickel concentration increased and the $\mathrm{Si} / \mathrm{Al}$ mol ratio of the framework decreased. As a result, the structural damage of zeolite increased accordingly.

Activity of the catalyst is required to determine the ability of the catalysts to convert a reactant into a desired product in a certain reaction. In this experiment, the catalyst is used for hydrocracking of heavy petroleum distillates $\left(200-300^{\circ} \mathrm{C}\right.$ fraction) of
Minas crude oil. The hydrocracking product actually consists of gas and liquid phases as well as solid phase. Carbonaceous deposits (cokes) as the solid phase product remains with the catalyst solid phase. Due to limited reactor condition, however, it was only liquid phase that has been isolated and analyzed. According to Fessenden and Fessenden (1986), based on the number of carbons, liquid petroleum distillates were grouped into gasoline (C5C10), kerosene (C11-C12), gas oil (C13-C17), and heavy gas oil (C18-C25). Thefore, the liquid phase of hydrocracking product was mainly grouped into gasoline, kerosene, gas oil, and heavy gas oil. Percentage of each fraction can be measured by comparing peak area of fraction component and total peak area of chromatogram.

Figure 3 showed that the main components of heavy petroleum distillates were gas oil and heavy gas oil. Although the conversion was not complete, it can be clearly seen that all catalysts performed the ability to convert heavy gas oil into lighter fraction as indicated by the decrease of heavy gas oil fraction concomitant with the increase of the lighter fraction. Thermal and fly ash hydrocrackings were able to decrease heavy gas oil fraction resulting gas oil as the main fraction concomitant with kerosene, however, it failed to increase gaso- 

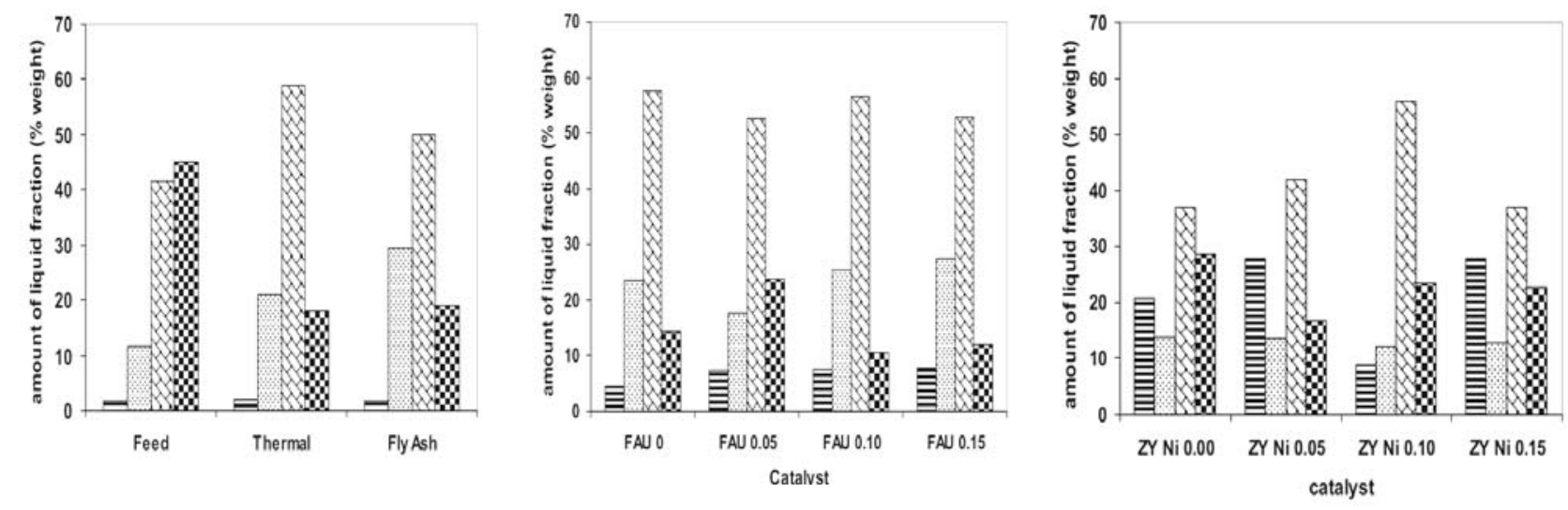

Egasoline $\square$ kerosene $₫$ gas oil $\otimes$ heavy gas oil

Figure 3. The composition of feed and hydrocracking product of heavy petroleum distillates over Ni-faujasite and Nizeolite Y catalysts

line fraction. Although gas oil fraction still dominated the hydrocracking product, in contrast, the composition of gasoline fraction in the hydrocracking product over $\mathrm{Ni}$-faujasite and $\mathrm{Ni}$-zeolite $\mathrm{Y}$ catalysts increased accordingly. Ni-faujasite catalysts were better than Ni-zeolite Y catalysts in the conversion of heavy gas oil, whereas Nizeolite $\mathrm{Y}$ catalyst produced the higher amount of gasoline.

\section{Conclusion}

Hydrothermal synthesis of faujasite from fly ash via reflux pretreatment of fly ash with $\mathrm{HCl}$ before fusion with $\mathrm{NaOH}$ fusion with $\mathrm{NaOH}$ has resulted faujasite selectively with thermal stability as high as commercial zeolite $\mathrm{NaY}$. In the preparation of nickel containing catalysts by ion exchange method under similar initial concentration of nickel, due to the lower $\mathrm{Si} / \mathrm{Al}$ mol ratio of the faujasite obtained, the amount of nickel loaded on faujasite was higher than those on zeolite Y, however, the structural damage of faujasite was higher than those of zeolite Y. In the hydrocracking of heavy petroleum distillates, although the conversion was not complete, it can be clearly seen that Ni-faujasite catalysts performed the ability to convert heavy gas oil into lighter fraction.

\section{References}

[1] Amrhein, C., Haghnia, G. H., Kim, T. S., Mosher, P. A., Gagajena, R. C., Amanios, T., and Torre, T. D. L., 1996, "Synthesis and Properties of Zeolites from Coal Fly Ash", Environ. Sci. Technol., 30(3), 735-742.

[2] Chang, H-L., and Shih, W-H., 2000, "Synthesis of Zeolites A and X from Fly Ashes and Their Ion-Exchange Behavior with Cobalt Ions", Ind. Eng. Chem. Res., 39, 4185-4191.

[3] Fessenden, R.J., and Fessenden, J.S., 1986, "Organic Chemistry", $3^{\text {rd }}$ Edition, Wadsworth, Inc, Belmont, California, 105109.

[4] Lin, C-F., and Hsi, H-C., 1995, "Resources Recovery of Waste Fly Ash: Synthesis of Zeolite-like Materials", Environ. Sci. Technol., 29(4), 1109-1117.

[5] Querol, X., Alastuey, A., Soler, A.L., Plana, F., Andres, J.M., Juan, R., Ferrer, P., and Ruiz, C.R., 1997, "A Fasat Method for Recycling Fly Ash: Microwave-Assisted Zeolite Synthesis", Environ. Sci. Technol., 31, 25272533.

[6] Shigemoto, N. , Hayashi, H., and Miyaura, K., 1993, "Selective Formation of Na-X Zeolite from Coal Fly Ash by Fusion with Sodium Hydroxide Prior to Hydrothermal Reaction", J. Mater. Sci., 28, 4781-4786.

[7] Shih, W-H., and Chang, H-L., 1996, "Conversion of Fly Ash into Zeolites for IonExchange Applications", Mater. Lett., 28, 263-268. 
[8] Singer, A., and Berkgaut, V., 1995, "Cation Exchange Properties of Hydrothermal Treated Coal Fly Ash", Environ. Sci. Technol., 27(7), 1748-1753.

[9] Susilowati, D., Arryanto, Y., dan Sutarno, 2000, "Pemanfaatan Abu Layang Batubara sebagai Bahan Dasar Sintesis Zeolit dengan Metoda Reaksi Hidrotermal Melalui Refluks $\mathrm{HCl}$ sebagai Perlakuan Awal", Prosiding Seminar Nasional Kimia VIII, Jurusan Kimia Fakultas MIPA, Universitas Gadjah Mada, Yogyakarta, 271-278

[10] Sutarno, Arryanto, Y., dan Yulianto, I., 2000, "Pemanfaatan Limbah Abu Layang Batubara sebagai Bahan Dasar Sintesis Faujasit dengan Metoda Peleburan-Reaksi Hidrotermal" Prosiding Seminar Nasional
Kimia VIII, Jurusan Kimia Fakultas MIPA, Universitas Gadjah Mada, Yogyakarta, 265270.

[11] Sutarno, Arryanto, Y., dan Hamidah, N., 2001, "Sintesis Zeolit Tipe Faujasit dari Abu Layang dengan Metoda Pembibitan dan Pemeraman", Prosiding Seminar Nasional Kimia IX, Jurusan Kimia Fakultas MIPA, Universitas Gadjah Mada, Yogyakarta, 241248.

[12] Zhao, X.S., Lu, G.Q., and Zhu, H.Y., 1997, "Effect of Ageing and Seeding on the Formation of Zeolite Y from Coal Fly Ash", J. Porous Mater. 4(4), 245-252. 